\title{
Long-Term Irrigation with Saline Water Decreases Soil Nutrients, Diversity of Bacterial Communities, and Cotton Yields in a Gray Desert Soil in China
}

\author{
Huinan Guo ${ }^{1}$, Xiaodong Shi ${ }^{1}$, Lijuan Ma ${ }^{1}$, Tao Yang ${ }^{2 *}$, Wei Min ${ }^{1 * *}$ \\ ${ }^{1}$ Department of Resources and Environmental Science, Shihezi University, Shihezi, \\ Xinjiang 832003, People's Republic of China \\ ${ }^{2}$ Institute of Soil and Fertilizer and Agricultural Water-Saving of Xinjiang Agricultural Science Academy
}

Received: 19 December 2019

Accepted: 6 April 2020

\begin{abstract}
Irrigation with saline water alters the soil environment, thereby influencing soil microbial processes and crop growth. The objective of this field experiment was to compare the effects of long-term irrigation with saline water or freshwater on cotton growth, soil physicochemical properties, and bacterial community structure. High-throughput sequencing of DNA of the 16S rRNA gene was used to assess the composition of bacterial communities. Saline-water irrigation significantly increased soil salinity and significantly decreased $\mathrm{pH}$, soil organic matter, total nitrogen, and biomass and yield of cotton. Cotton biomass and yield were negatively correlated with soil salinity but were positively correlated with soil organic matter, and total nitrogen. Compared with fresh water irrigation, irrigation with saline water significantly decreased the Shannon diversity index of the bacterial community. Compared with freshwater irrigation, saline-water irrigation significantly increased the relative abundance of two phyla of bacteria (Gemmatimonadetes and Actinobacteria) and decreased that of two (Proteobacteria and Acidobacteria). In addition, the relative abundance of 5 genera was significantly higher (Sphingomonas, Gemmatimonas, Gaiella, Solirubrobacter, and Nocardioides) and that of 7 was significantly lower (RB41, H16, Haliangium, Nitrospira, Lysobacter, Acidobacteria_bacterium, and Bryobacter) in the saline-water treatment. Soil salinity and $\mathrm{pH}$ were the major environmental factors that shaped bacterial communities. According to LEfSe analysis, only 3 indicator species were associated with saline-water irrigation, whereas 5 indicator species were associated with freshwater irrigation. Overall, long-term irrigation with saline water adversely affected soil properties and led to decreases in soil bacterial community diversity and cotton growth and yield. These results contribute to a more comprehensive understanding of bacterial communities in saline environments.
\end{abstract}

Keywords: water salinity, drip irrigation, bacterial community diversity, LEfSe analysis, cotton

\footnotetext{
*e-mail:2874519408@qq.com
}

**e-mail: minwei555@126.com 


\section{Introduction}

Freshwater scarcity and high-salinity water are threats to the sustainable development of agriculture in many regions, particularly in arid and semiarid regions. However, some areas have substantial sources of saline water, and treated or untreated saline water is the only source for irrigation to maintain crop productivity. For example, Xinjiang Province in northwest China has an arid or semiarid climate characterized by low annual precipitation and high evaporation, which leads to water shortage and soil salinization [1]. In addition, the main agricultural water sources in Xinjiang generally contain soluble salts [2]. The continual irrigation with saline water can adversely affect agricultural soils, resulting in soil salinization and land degradation [3, 4]. Moreover, regardless of the measures taken to prevent or limit salt accumulation in soil [5], irrigation with saline water will inevitably alter the physical, chemical, and biological properties of the soil.

As the principal drivers of nutrient cycling, soil microbial communities play a pivotal role in maintaining soil ecosystem function [6,7]. Microbial communities participate directly in many important soil ecological processes, including organic matter decomposition, aggregate formation, and nutrient cycling. Soil microbial community structure and diversity are increasingly used as relevant soil quality indicators [8]. Several studies report that salt is a major stress that affects microbial growth and community structure in soils, thereby altering microbially mediated processes [9]. Increases in soil salt concentration adversely affect soil microbial biomass, basal respiration, and activity [10, 11, 12]. Soil enzyme activity is also negatively correlated with soil salinity [13]. Soil microbial communities can adapt to salt stress in multiple ways (reflected in microbial biomass and community composition) and maintain their populations in an extreme soil environment [14]. Salinity is implicated as a major factor regulating microbial community composition and diversity across many different soil environments [15]. The structure of soil bacterial communities is an important determinant of soil fertility, because the communities participate in all biogeochemical cycles. However, the understanding of how irrigation with saline water affects soil bacterial community structure and diversity remains fragmented and incomplete.

Researchers have long been interested in the effects of long-term irrigation with saline water on soil ecology. The objective of this long-term field experiment was to evaluate the effects of irrigation with saline water on (i) soil properties and cotton growth, (ii) bacterial community composition and diversity, and (iii) the relations between bacterial communities and soil properties. The results of this study contribute important information for the management of soil and saline water resources in arid regions.

\section{Materials and Methods}

\section{Characteristics of the Study Area}

A long-term field experiment was conducted at the Shihezi University Agricultural Experimental Station at $44^{\circ} 18^{\prime} \mathrm{N}, 86^{\circ} 02^{\prime} \mathrm{E}$. The region is classified as a temperate arid zone. The average temperature is $7.8^{\circ} \mathrm{C}$, and 168 to 171 frost-free days occur each year. The annual average sunshine time ranges from 2,721 to $2,818 \mathrm{~h}$. The annual average evaporation ranges from 1,500 to $2,000 \mathrm{~mm}$, and the annual average precipitation ranges from 110 to $210 \mathrm{~mm}$, without notable annual variation. The soil is an alluvial gray desert soil. The soil physicochemical properties in the 0 to $30 \mathrm{~cm}$ depth before the experiment were the following: electrical conductivity $\left(\mathrm{EC}_{1 \cdot 5}\right)$, $0.13 \mathrm{dS} \mathrm{m} \mathrm{m}^{-1} ; \mathrm{pH}_{1: 2.5}, 7.90$; soil organic matter (SOM), $16.8 \mathrm{~g} \mathrm{~kg}^{-1}$; total nitrogen (TN), $1.08 \mathrm{~g} \mathrm{~kg}^{-1}$; available phosphorus, $25.9 \mathrm{mg} \mathrm{kg}^{-1}$; and available potassium, $253 \mathrm{mg} \mathrm{kg}^{-1}$.

\section{Experimental Design}

The experiment was conducted for 9 years (2009 to 2017) in a completely randomized block design with 3 replicates of 2 treatments of irrigation water salinity. The 2 treatments were (1) freshwater (FW) with an electrical conductivity (ECw) of $0.35 \mathrm{dS} \mathrm{m}^{-1}$ and (2) saline water (SW) with an ECW of $8.04 \mathrm{dS} \mathrm{m}^{-1}$. The fresh water was obtained from a well in study area, and the saline water was obtained by adding equal weights of $\mathrm{CaCl}_{2}$ and $\mathrm{NaCl}$ to the well water. Table 1 shows the chemical composition of the irrigation water. A tank was used to store the saline water, and the $\mathrm{ECw}$ of the desired irrigation water salinity was calibrated using a conductivity meter.

A traditional cotton cultivar (Gossypium hirsutum L. 'Xinluzao No. 52') was planted in late April and harvested in late September in the experimental plots each year. Each plot $(16 \mathrm{~m}$ long $\times 1.2 \mathrm{~m}$ wide $)$ had 4 rows of cotton. The plots were mulched with one sheet of transparent polyethylene plastic film. Two drip irrigation lines were installed under the transparent polyethylene plastic film. Phosphorous, $105 \mathrm{~kg} \mathrm{P}_{2} \mathrm{O}_{5}$ $\mathrm{ha}^{-1}$, and potassium, $60 \mathrm{~kg} \mathrm{~K}_{2} \mathrm{O} \mathrm{ha}$, were applied at planting. A total of $360 \mathrm{~kg} \mathrm{~N} \mathrm{ha}^{-1}$ was applied via the drip irrigation system in 5 applications in each plot from June to August. The same irrigation amount (450 $\mathrm{mm}$ ) was applied to each plot during the cotton-growing season, and the same cultivation techniques were used during the 9 years of the study.

\section{Soil and Plant Sampling}

Soil samples, 0 to $20 \mathrm{~cm}$, were collected in each plot on 30 July 2018 (i.e., the tenth year of the longterm study). The soil samples were packed with ice packs and transported to the laboratory. Soil samples were passed through a $2-\mathrm{mm}$ sieve to remove plant 
Table 1. Chemical characteristics of the fresh water and saline water in this study.

\begin{tabular}{|c|c|c|c|c|c|c|c|c|c|}
\hline \multirow{2}{*}{ Water salinity } & \multirow{2}{*}{$\mathrm{pH}$} & \multirow{2}{*}{$\mathrm{SAR}$} & \multicolumn{6}{|c|}{ Ion concentration (meq/L) } \\
\cline { 5 - 11 } & & & $\mathrm{K}^{+}$ & $\mathrm{Na}^{+}$ & $\mathrm{Ca}^{2+}$ & $\mathrm{Mg}^{2+}$ & $\mathrm{HCO}_{3}^{-}$ & $\mathrm{Cl}^{-}$ & $\mathrm{SO}_{4}^{2-}$ \\
\hline $\mathrm{FW}$ & 7.52 & 0.16 & 0.33 & 0.22 & 2.44 & 1.18 & 0.98 & 2.46 & 0.73 \\
\hline $\mathrm{SW}$ & 7.09 & 8.91 & 0.33 & 43.04 & 45.50 & 1.18 & 1.15 & 88.00 & 0.83 \\
\hline
\end{tabular}

roots, macrofauna, and stones. Subsamples for DNA extraction were frozen at $-80^{\circ} \mathrm{C}$.

At harvest, the biomass of cotton was sampled and measured using 3 representative cotton plants selected for each treatment. Plants were green-killed at $105^{\circ} \mathrm{C}$. After $30 \mathrm{~min}$, they were oven-dried at $80^{\circ} \mathrm{C}$ for $72 \mathrm{~h}$ and weighed. Seed cotton yield was measured by weighing the seed cotton in the field.

\section{Soil Chemical Analyses}

Soil water content (SWC) was measured by oven-drying the soil at $105^{\circ} \mathrm{C}$ for $1 \mathrm{~d}$. Soil salinity (ECe) and $\mathrm{pH}$ were determined using an MP521 Lab $\mathrm{pH} /$ Conductivity meter. The $\mathrm{pH}$ was measured at a 1:2.5 soil:water ratio. Soil organic matter and soil $\mathrm{TN}$ were measured using $\mathrm{K}_{2} \mathrm{Cr}_{2} \mathrm{O}_{7}-\mathrm{H}_{2} \mathrm{SO}_{4}$ oxidationreduction titration and semimicro-Kjeldahl digestion methods, respectively.

\section{DNA Extraction and Pyrosequencing Analysis}

Soil total bacterial DNA was extracted from $0.25 \mathrm{~g}$ of a fresh soil sample using a Fast DNA SPIN extraction kit (MP Biomedicals, Santa Ana, CA, USA) according to the manufacturer's protocol. The concentration and purification of DNA were measured using a NanoDrop 2000 UV-vis spectrophotometer (Thermo Fisher Scientific, Waltham, MA, USA), and DNA quality was measured by $0.8 \%$ agarose gel electrophoresis. The DNA was stored at $-20^{\circ} \mathrm{C}$ before analysis.

To analyze the taxonomic composition of soil bacterial communities, the entire region of the 16S rRNA gene was selected for amplification and subsequent high-throughput sequencing of the PCR products. The V3-V4 hypervariable region of the bacterial 16S rRNA gene was amplified with the primers 341F (5'-CCTACGGGNGGCWGCAG-3') and 805R (5'-GACTACHVGGGTATCTAATCC-3') by using a thermocycler PCR system (GeneAmp 9700, ABI, USA). PCR reactions were performed in triplicate in a $20-\mu \mathrm{L}$ mixture containing $4 \mu \mathrm{L}$ of $5 \times$ FastPfu Buffer, $2 \mu \mathrm{L}$ of $2.5 \mathrm{mM}$ dNTPs, $0.8 \mu \mathrm{L}$ of each primer $(5 \mu \mathrm{M})$, $0.4 \mu \mathrm{L}$ of FastPfu Polymerase, and $10 \mathrm{ng}$ of template DNA. The PCR reactions were conducted using the following program: $2 \mathrm{~min}$ of initial denaturation at $98^{\circ} \mathrm{C} ; 25$ cycles of $15 \mathrm{~s}$ at $98^{\circ} \mathrm{C}, 30 \mathrm{~s}$ for annealing at $55^{\circ} \mathrm{C}$, and $30 \mathrm{~s}$ for elongation at $72^{\circ} \mathrm{C}$; and a final extension at $72^{\circ} \mathrm{C}$ for $5 \mathrm{~min}$. The $\mathrm{PCR}$ products were extracted from a $2 \%$ agarose gel and further purified using an AxyPrep DNA Gel Extraction Kit (Axygen Biosciences, Union City, CA, USA) and then quantified using QuantiFluor ${ }^{\mathrm{TM}}$-ST (Promega, USA) according to the manufacturer's protocol. After the individual quantification step, purified amplicons were pooled in equimolar amounts and paired-end sequenced $(2 \times 300$ bp) using the Illlumina MiSeq platform with MiSeq Reagent Kit v3 at the Beijing Biomarker Technology Co., Ltd (Beijing, China). Each replicate was analyzed 3 times by high-throughput sequencing. The median of the 3 measurements was used as the value for each replicate.

\section{Statistical Analyses}

One-way ANOVA and Pearson's correlation analysis were conducted using the SPSS statistical software package (v. 19.0). Tukey's test was used to determine significant differences between the treatments $(P<0.05)$. The sequence data were analyzed using QIIME and R packages (v. 3.2.0). The richness and diversity indexes were calculated using Mothur software (v. 1.30.1). The visualization analysis of classification and abundance used MEGAN software. Principal component analysis (PCA), Redundancy analysis (RDA), using Canoco v. 4.5, was used to identify the soil properties that explained the patterns of similarity in the structure of soil bacterial communities. To identify statistically different biomarker taxa between treatments, linear discriminant analysis (LDA) effect size (LEfSe) was calculated using Visual Genomics.

\section{Results}

\section{Biomass and Yield}

Saline water irrigation significantly decreased biomass and seed cotton yield (Fig. 1). The average biomass and seed cotton yield were $45.23 \%$ and $46.80 \%$ lower, respectively, in the SW treatment than in the FW treatment.

\section{Soil Properties}

Saline water irrigation significantly increased SWC and ECe but significantly decreased soil $\mathrm{pH}$, SOM, and TN (Table 2). Biomass and seed cotton yield were positively correlated with SOM and TN (Fig. 2). 

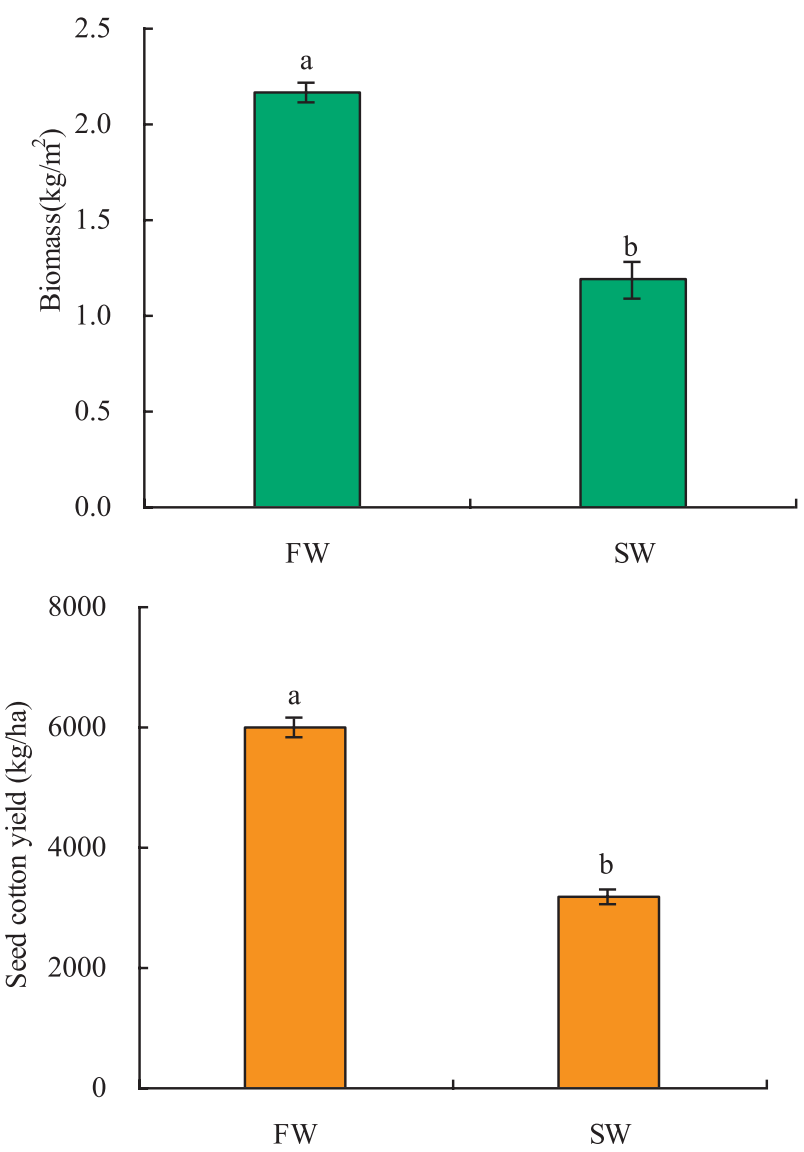

Fig. 1. Effects of fresh water $\left(\mathrm{FW}, 0.35 \mathrm{dS} \mathrm{m} \mathrm{m}^{-1}\right)$ and saline water ( $\mathrm{SW}, 8.04 \mathrm{dS} \mathrm{m}^{-1}$ ) irrigation on the biomass and yield of cotton. Error bars represent standard deviations $(n=3)$. Different lowercase letters indicate significant differences $(P<0.05)$ between the FW and SW treatments.

However, biomass and seed cotton yield were negatively correlated with SWC and ECe.

\section{Sequence Analysis and Alpha Diversity}

Good's coverage of soil bacteria among all soil samples was higher than $99 \%$ in both irrigation treatments, which indicated that the depth of coverage reasonably represented the actual situation of the samples (Table 3). The number of operational taxonomic units (OTUs) was significantly higher in SW $(1,950)$ than in FW $(1,889)$. Although the Shannon index was significantly higher, the ACE, Chaol, and Simpson indexes were significantly lower in FW than in SW.

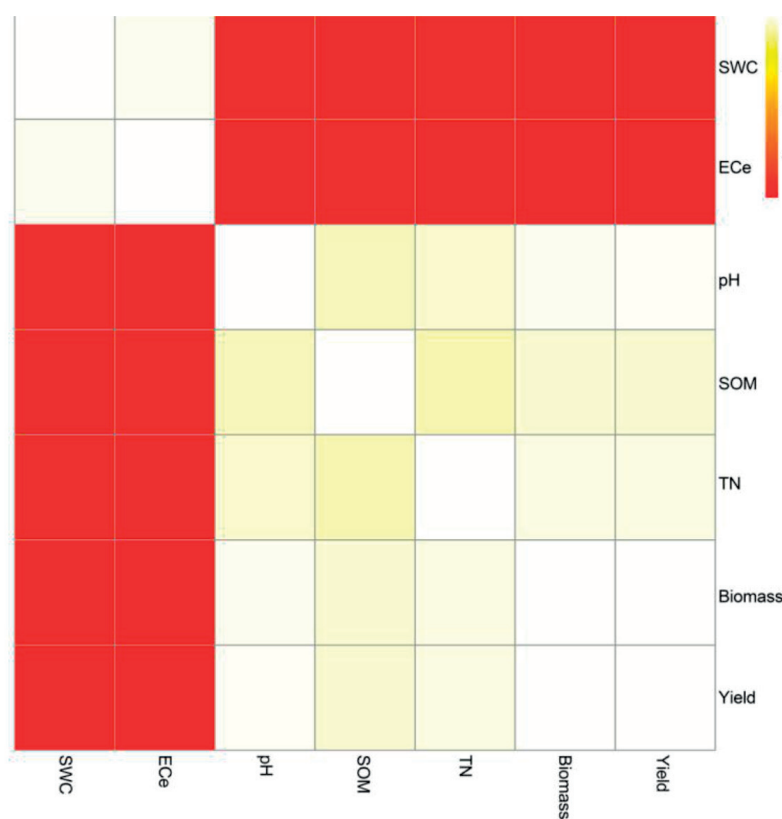

Fig. 2. Heat map of the correlations between soil properties and between soil properties and biomass and seed cotton yield. SWC, soil water content; ECe, saturation conductivity; SOM, soil organic matter; $\mathrm{TN}$, soil total nitrogen.

\section{Principal Component Analysis (PCA)}

The PCA revealed that bacterial communities were clustered into two groups, with samples from the same treatment clustered together in all cases (Fig. 3). At the phylum level (Fig. 3a), the PCA1 and PCA2 axes explained $81.5 \%$ and $9.21 \%$ of the total variability, respectively. At the genus level (Fig. 3b), the PCA1 and PCA2 axes explained $80.7 \%$ and $10.4 \%$ of the total variability, respectively. The results indicate selectivity and adaptation of soil bacteria to freshwater or saline water irrigation.

\section{Bacterial Community Structure}

Soil bacterial communities were affected by irrigation water salinity (Fig. 4). The 4 dominant bacterial phyla across all soil samples with relative abundance greater than $10 \%$ were Proteobacteria $(28.41 \%$ to $30.44 \%)$, Actinobacteria $(16.66 \%$ to $22.15 \%)$, Gemmatimonadetes $(13.05 \%$ to $17.75 \%)$, and Acidobacteria (10.82\% to $13.25 \%)$. The 4 phyla

Table 2. Soil chemical and physical properties in fresh water and saline water irrigation treatments after 10 consecutive seasons of cotton.

\begin{tabular}{|c|c|c|c|c|c|}
\hline Water salinity & SWC & ECe $\left.(\mathrm{dS} \mathrm{m})^{-1}\right)$ & $\mathrm{pH}$ & $\mathrm{SOM}\left(\mathrm{g} \mathrm{kg}^{-1}\right)$ & $\mathrm{TN}\left(\mathrm{g} \mathrm{kg}^{-1}\right)$ \\
\hline FW & $13.01 \% \mathrm{~b}$ & $3.00 \mathrm{~b}$ & $8.00 \mathrm{a}$ & $17.83 \mathrm{a}$ & $0.74 \mathrm{a}$ \\
\hline SW & $17.56 \% \mathrm{a}$ & $11.62 \mathrm{a}$ & $7.75 \mathrm{~b}$ & $16.97 \mathrm{~b}$ & $0.65 \mathrm{~b}$ \\
\hline
\end{tabular}

Note: Different letters within a column indicate significant differences between treatments $(P<0.05)$. Values are the mean $(\mathrm{n}=3)$. $\mathrm{FW}$, freshwater $\left(0.35 \mathrm{dS} \mathrm{m}^{-1}\right)$; SW, saline water $\left(8.04 \mathrm{dS} \mathrm{m}^{-1}\right)$; SWC, soil water content; ECe, saturation conductivity; SOM, soil organic matter; $\mathrm{TN}$, soil total nitrogen. 
Table 3. Richness and diversity indexes of soil bacterial communities in fresh water and saline water irrigation treatments after 10 consecutive seasons of cotton.

\begin{tabular}{|c|c|c|c|c|c|c|}
\hline Water salinity & OTU & Coverage & ACE & Chao1 & Simpson & Shannon \\
\hline FW & $1889 \mathrm{~b}$ & $0.9955 \mathrm{a}$ & $1952 \mathrm{~b}$ & $1968 \mathrm{~b}$ & $0.0028 \mathrm{~b}$ & $6.64 \mathrm{a}$ \\
\hline SW & $1950 \mathrm{a}$ & $0.9951 \mathrm{a}$ & $2025 \mathrm{a}$ & $2047 \mathrm{a}$ & $0.0030 \mathrm{a}$ & $6.60 \mathrm{~b}$ \\
\hline
\end{tabular}

Note: Different letters within a column indicate significant differences between treatments $(P<0.05)$. Values are the mean $(\mathrm{n}=3)$. $\mathrm{FW}$, fresh water $\left(0.35 \mathrm{dS} \mathrm{m}^{-1}\right)$; SW, saline water $\left(8.04 \mathrm{dS} \mathrm{m}^{-1}\right)$; OTU, operational taxonomic unit; Coverage, Good's nonparametric coverage estimator.

accounted for approximately $76 \%$ of the bacterial abundance in the irrigation treatments. Other phyla with high relative abundance $(<1.0 \%)$ included,

a)

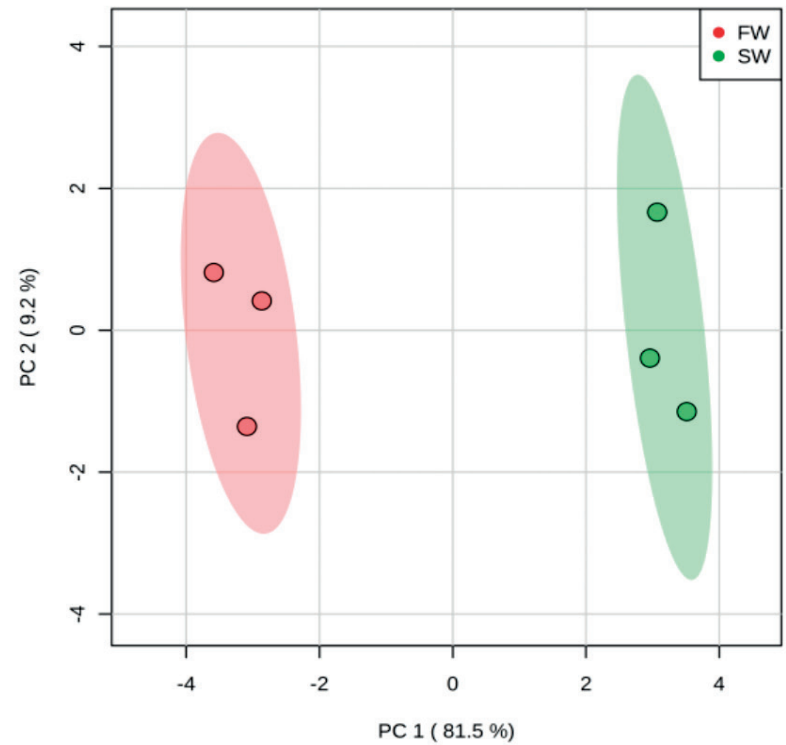

b)

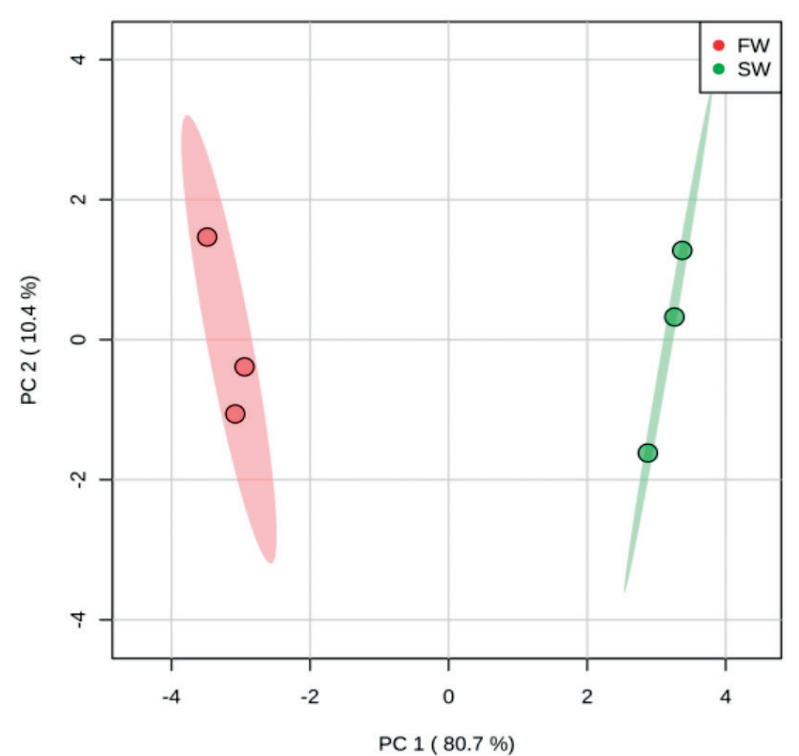

Fig. 3. Principal component analysis (PCA) of samples based on a) phylum distribution and b) genus-level information. FW, fresh water $\left(0.35 \mathrm{dS} \mathrm{m}^{-1}\right)$; $\mathrm{SW}$, saline water $\left(8.04 \mathrm{dS} \mathrm{m}^{-1}\right)$. in decreasing order, Chloroflexi, Bacteroidetes, Nitrospirae, Planctomycetes, and Verrucomicrobia. The relative abundance of the other bacterial phyla was less than 1\% (Saccharibacteria (0.62\%), Armatimonadetes $(0.47 \%)$, Firmicutes (0.37\%), Latescibacteria (0.33\%), Elusimicrobia (0.24\%), Cyanobacteria (0.14\%), other phyla $(0.51 \%))$.

Soil bacterial phyla were separated on the basis of the 2 irrigation treatments (Fig. 5), indicating high similarity among the bacterial communities in the samples from each treatment. In the SW treatment, the relative abundance of Gemmatimonadetes, Chloroflexi, Actinobacteria, Bacteroidetes, Saccharibacteria, and Elusimicrobia increased significantly. By contrast, the relative abundance of Proteobacteria, Acidobacteria, Nitrospirae, Planctomycetes, Armatimonadetes, Verrucomicrobia, and Latescibacteria decreased significantly in the SW treatment.

At the genus level, the relative abundance of 6 genera was $>1 \%$, and they accounted for $73.45 \%$ of the total sample sequences (Fig. 6). The 6 dominant genera across all soil samples were bacterium (60.96\%), RB41 (4.69\%), Sphingomonas (3.10\%), H16 (1.87\%), Nitrospira (1.58\%), and Haliangium (1.25\%).

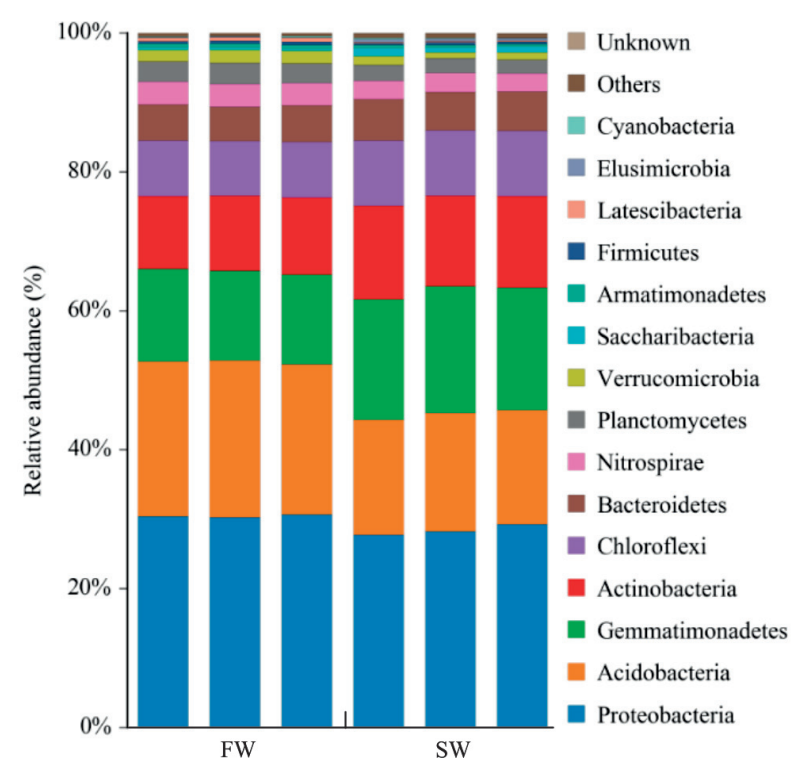

Fig. 4. Relative abundance (\%) of the 15 most common bacterial phyla after 10 years of fresh water $\left(\mathrm{FW}, 0.35 \mathrm{dS} \mathrm{m}^{-1}\right)$ and saline water $\left(\mathrm{SW}, 8.04 \mathrm{dS} \mathrm{m}^{-1}\right)$ irrigation. 


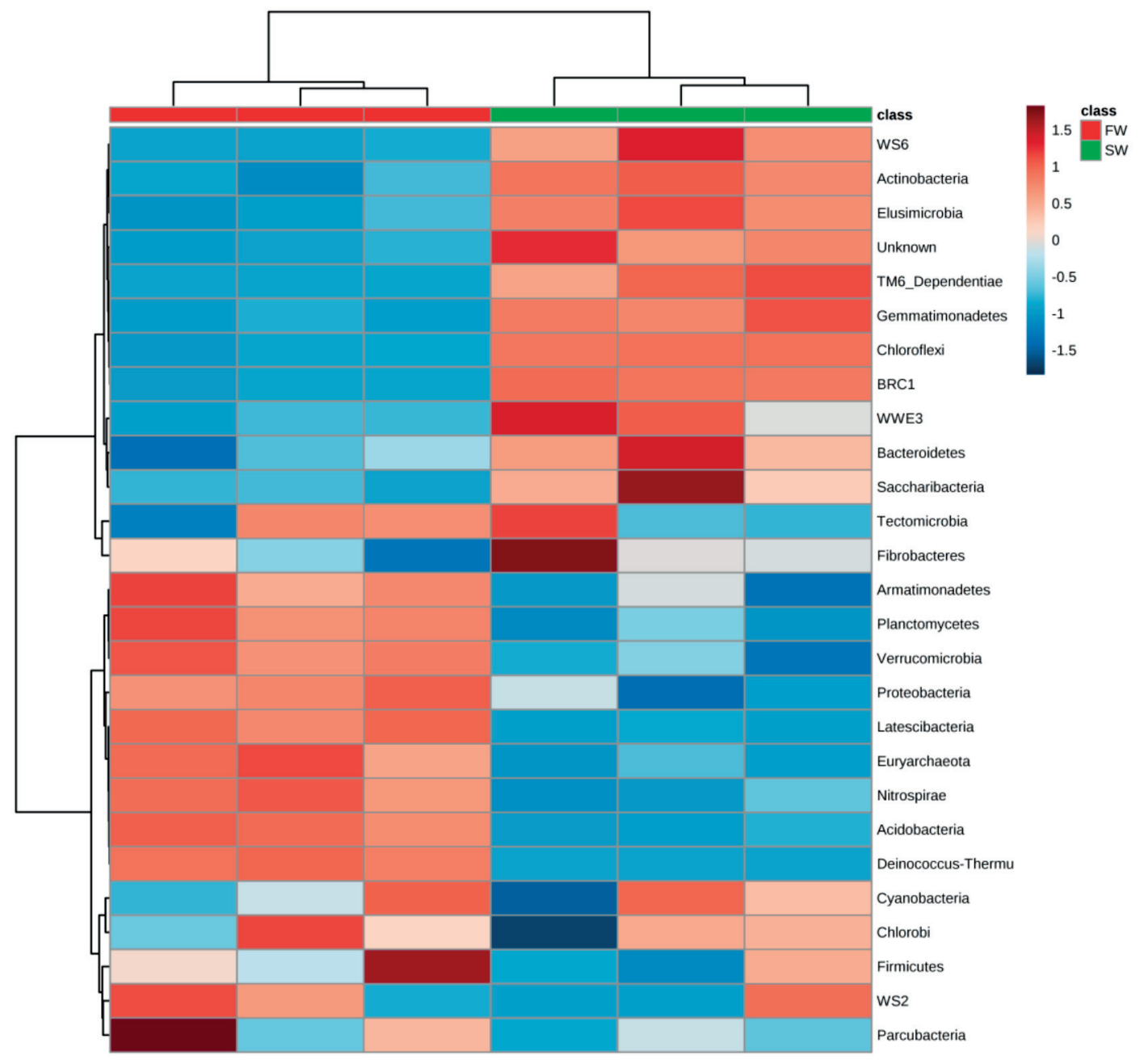

Fig. 5. Heat map of the relative abundance of dominant bacterial phyla. The relative values are indicated by color intensity in the legend in the upper right. $\mathrm{FW}$, fresh water $\left(0.35 \mathrm{dS} \mathrm{m}^{-1}\right)$; SW, saline water $\left(8.04 \mathrm{dS} \mathrm{m}^{-1}\right)$.

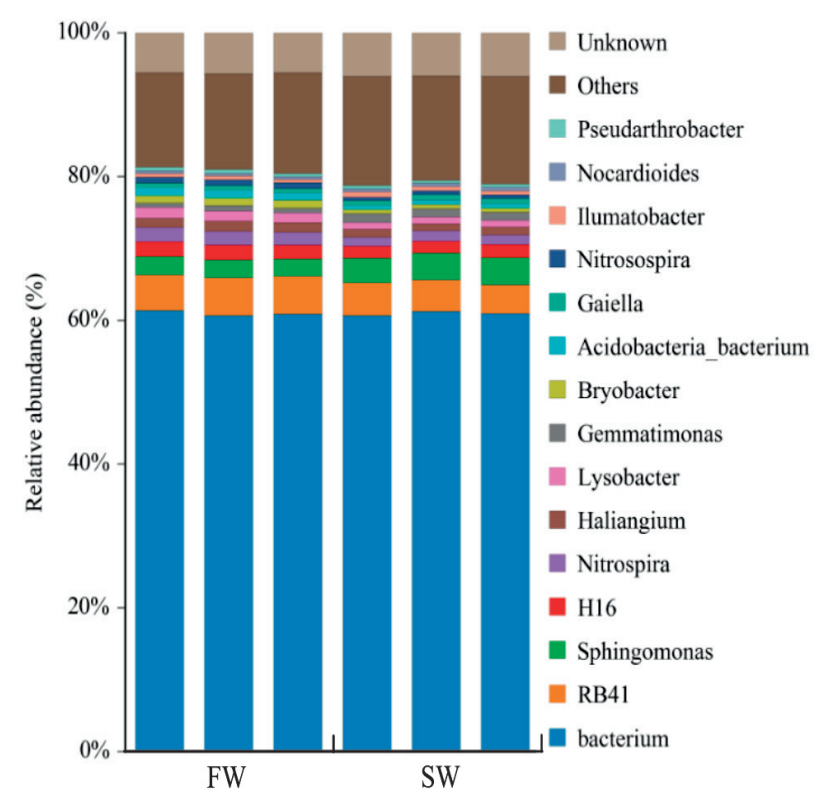

Fig. 6. Relative abundance (\%) of the 15 most common bacterial genera after 10 years of fresh water $\left(\mathrm{FW}, 0.35 \mathrm{dS} \mathrm{m}^{-1}\right)$ and saline water (SW, $8.04 \mathrm{dS} \mathrm{m}^{-1}$ ) irrigation.
As shown in a heat map (Fig. 7), the relative abundance of bacterial genera differed between the treatments. Each row of the heat map shows the relative abundance of a different bacterial genus in a soil sample. The columns of the heat map represent the different samples in the 2 irrigation treatments. The cluster structure shows 2 main groups of bacterial genera separated by irrigation treatment, indicating high similarity among the bacterial communities in the samples from each treatment. In the SW treatment, the relative abundance of Sphingomonas, Gemmatimonas, Gaiella, Solirubrobacter, and Nocardioides increased significantly. By contrast, the relative abundance of RB41, H16, Haliangium, Nitrospira, Lysobacter, Acidobacteria_bacterium, and Bryobacter decreased significantly in the SW treatment.

\section{Redundancy Analysis and Correlation Analysis}

The RDA was performed to determine the influence of various environmental parameters on bacterial community structure. As shown in Fig. 8a), at the phylum level, axes 1 and 2 explained $97.97 \%$ of the 


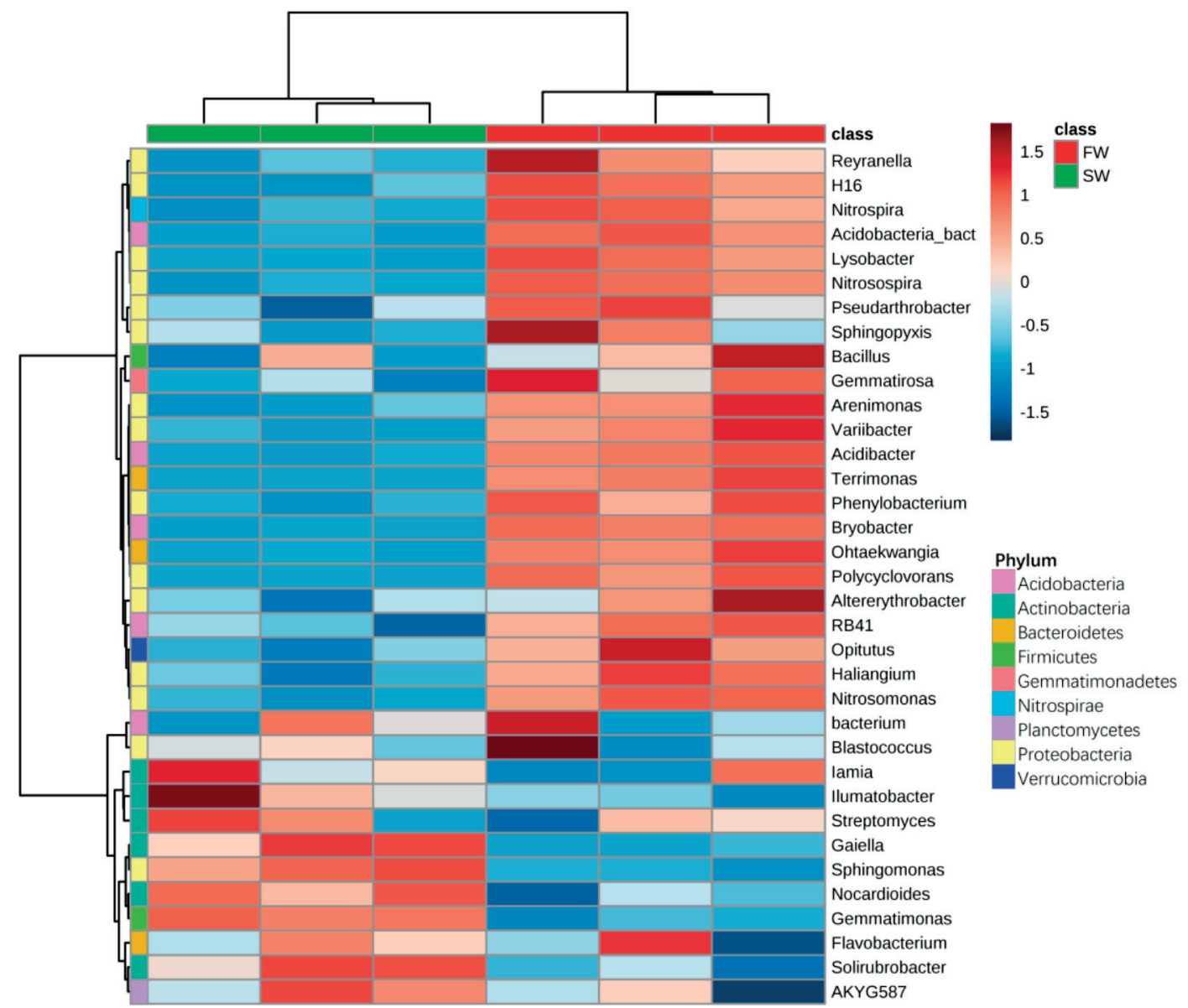

Fig. 7. Heat map of the relative abundance of dominant bacterial genera. The relative values are indicated by color intensity in the legend in the upper right. $\mathrm{FW}$, fresh water $\left(0.35 \mathrm{dS} \mathrm{m}^{-1}\right) ; \mathrm{SW}$, saline water $\left(8.04 \mathrm{dS} \mathrm{m}^{-1}\right)$.

variation in soil bacterial community. In the RDA plot of bacterial community structure at the phyla level, ECe had the longest arrow (\% variation explained $=79.5 \%)$. The phyla Proteobacteria, Acidobacteria, Nitrospirae, Planctomycetes, Verrucomicrobia, Armatimonadetes, Firmicutes, and Latescibacteria were clustered to the edge of the $\mathrm{FW}$ treatment and were negatively correlated with soil salinity (ECe) but were positively correlated with soil $\mathrm{pH}, \mathrm{SOM}$, and TN (Table 3). The phyla Gemmatimonadetes, Actinobacteria, Chloroflexi, Bacteroidetes, Saccharibacteria, and Elusimicrobia were clustered close to the SW treatment and were positively correlated with soil ECe (Table 4).

The correlations of soil bacterial community structure at the genus level with environmental factors were also analyzed using RDA (Fig. 8b). Axis 1 and axis 2 together explained $97.42 \%$ of the total variation in the genus-level composition of soil bacterial communities. In the RDA plot of bacterial community structure, the 2 longest arrows were ECe $(\%$ variation explained $=80.5 \%)$ and $\mathrm{pH}(\%$ variation explained $=7.1 \%$ ), with their direction closely correlated with RDA axis 1 and axis 2, respectively. These results indicated that both ECe and $\mathrm{pH}$ strongly influenced the genus-level structure of soil bacterial communities.
The correlations between soil properties and the relative abundance of bacterial genera are given in Table 5 .

\section{Indicator Bacteria}

A cladogram generated by LEfSe showed significant differences in taxa among the treatments (Fig. 9). In total, 8 bacterial clades were significantly different among the clades, with 5 in the FW treatment and 3 in the SW treatment, indicating that the number of potential biomarkers decreased as the water salinity increased. Acidobacteria, Proteobacteria, Subgroup 6, Betaproteobacteria, and Xanthomonadales were distinguished as indicator bacteria in the FW treatment by LEfSe analysis, whereas Gemmatimonadales, Alphaproteobacteria, and Actinobacteria were identified as indicator bacteria in the SW treatment.

\section{Discussion}

The ecological effects of irrigation with saline water on the soil environment are currently receiving more attention. In this study, soil salinity and water content both increased with saline water irrigation. This result 
Table 4. Pearson's coefficients of correlation between soil properties and relative abundance of bacterial phyla in a long-term experiment comparing freshwater and saline water irrigation in cotton.

\begin{tabular}{|c|c|c|c|c|c|}
\hline & SWC & $\mathrm{ECe}$ & $\mathrm{pH}$ & $\mathrm{SOM}$ & $\mathrm{TN}$ \\
\hline Proteobacteria & -0.809 & $-0.881 *$ & $0.853 *$ & 0.737 & $0.964 * *$ \\
\hline Acidobacteria & $-0.967 * *$ & $-0.985^{* *}$ & $0.969 * *$ & $0.949 * *$ & $0.941 * *$ \\
\hline Gemmatimonadetes & $0.977 * *$ & $0.995 * *$ & $-0.950 * *$ & $-0.930 * *$ & $-0.974 * *$ \\
\hline Actinobacteria & $0.940 * *$ & $0.976^{* *}$ & $-0.980 * *$ & $-0.907 *$ & $-0.937 * *$ \\
\hline Chloroflexi & $0.969 * *$ & $0.994 * *$ & $-0.963 * *$ & $-0.937 * *$ & $-0.967 * *$ \\
\hline Bacteroidetes & $0.833^{*}$ & $0.841 *$ & $-0.823^{*}$ & $-0.871^{*}$ & $-0.858^{*}$ \\
\hline Nitrospirae & $-0.940 * *$ & $-0.968 * *$ & $0.971 * *$ & $0.932 * *$ & $0.902 *$ \\
\hline Planctomycetes & $-0.992 * *$ & $-0.976^{* *}$ & $0.923^{* *}$ & $0.977 * *$ & $0.914 *$ \\
\hline Verrucomicrobia & $-0.985^{* *}$ & $-0.966 * *$ & $0.908^{*}$ & $0.924 *$ & $0.947 * *$ \\
\hline Saccharibacteria & 0.734 & $0.825^{*}$ & -0.805 & -0.754 & $-0.858^{*}$ \\
\hline Armatimonadetes & $-0.961 * *$ & $-0.912 *$ & $0.834 *$ & $0.919 * *$ & $0.861 *$ \\
\hline Firmicutes & -0.373 & -0.521 & 0.416 & 0.494 & 0.483 \\
\hline Latescibacteria & $-0.967 * *$ & $-0.993 * *$ & $0.944 * *$ & $0.943 * *$ & $0.964 * *$ \\
\hline Cyanobacteria & -0.043 & -0.102 & 0.044 & 0.115 & -0.129 \\
\hline Elusimicrobia & $0.937 * *$ & $0.966^{* *}$ & $-0.953 * *$ & $-0.920 * *$ & $-0.950 * *$ \\
\hline
\end{tabular}

SWC, soil water content; ECe, saturation conductivity; SOM, soil organic matter; TN, soil total nitrogen. Correlation significant at $* 0.05$ or $* * 0.01$

is similar to that of Ahmed et al. [16], who reported that saline water irrigation increases soil salt concentrations. The increase in soil water content that occurred with the increase in irrigation water salinity can be explained primarily because of lower evapotranspiration rates with saline-water irrigation than with freshwater irrigation [17]. In this study, soil TN, SOM, and $\mathrm{pH}$ decreased with the increase in irrigation water salinity. The decline in soil $\mathrm{pH}$ observed as irrigation water salinity increased can be explained primarily because of the
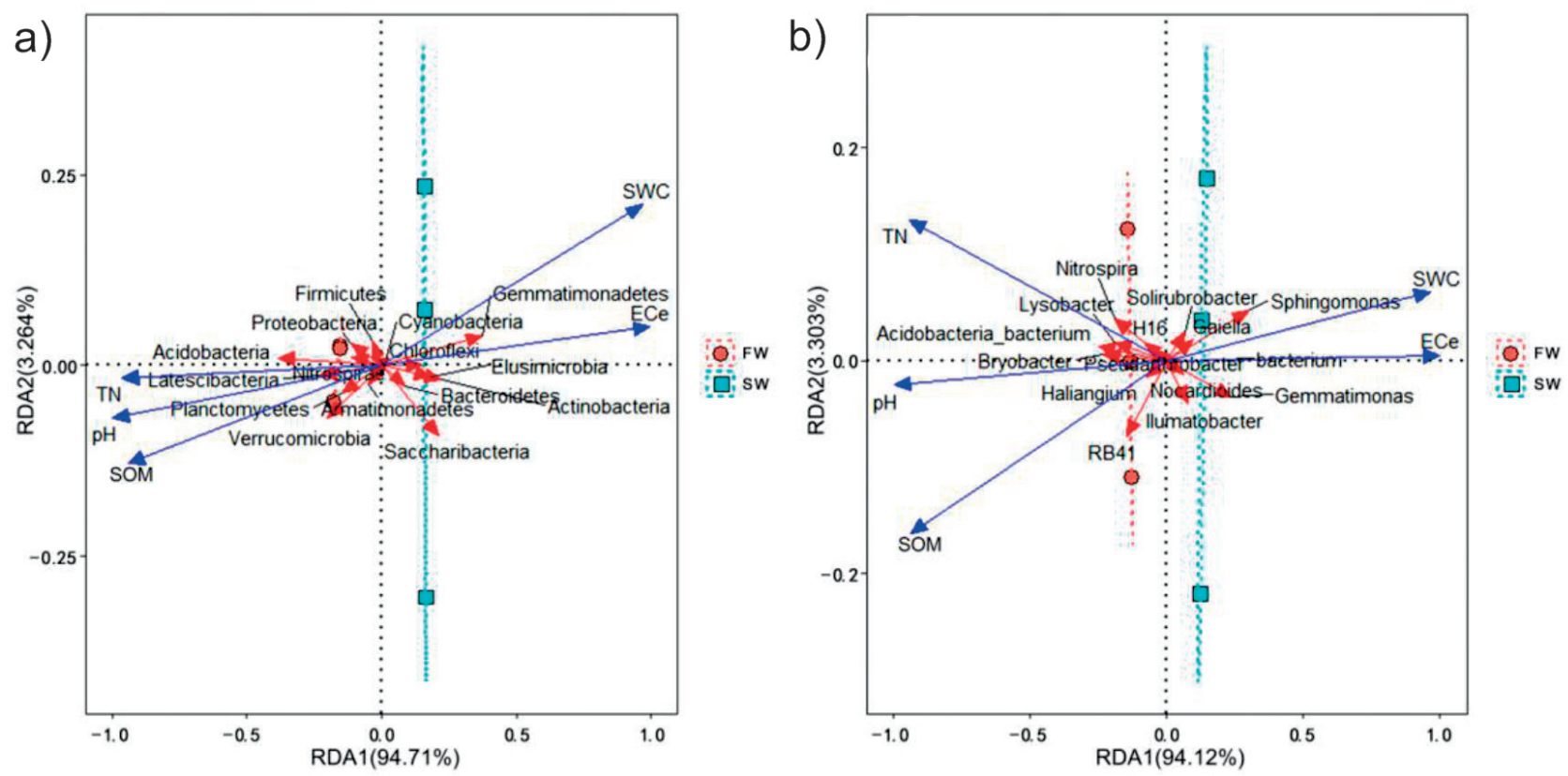

Fig. 8. Redundancy analysis (RDA) of samples based on a) phylum distribution and b) genus level information. SWC, soil water content; ECe, saturation conductivity; SOM, soil organic matter; TN, soil total nitrogen. $\mathrm{FW}$, fresh water $\left(0.35 \mathrm{dS} \mathrm{m}{ }^{-1}\right)$; $\mathrm{SW}$, saline water $\left(8.04 \mathrm{dS} \mathrm{m}^{-1}\right)$ 
Table 5. Pearson's coefficients of correlation between soil properties and relative abundance of bacterial genera in a long-term experiment comparing fresh water and saline water irrigation in cotton.

\begin{tabular}{|c|c|c|c|c|c|}
\hline & SWC & ECe & pH & SOM & TN \\
\hline Bacterium & 0.108 & -0.02 & 0.213 & -0.147 & -0.034 \\
\hline RB41 & $-0.908^{*}$ & $-0.921^{* *}$ & $0.839^{*}$ & $0.949^{* *}$ & 0.804 \\
\hline Sphingomonas & $0.965^{* *}$ & $0.989^{* *}$ & $-0.941^{* *}$ & $-0.930^{* *}$ & $-0.919^{* *}$ \\
\hline H16 & $-0.943^{* *}$ & $-0.964^{* *}$ & $0.973^{* *}$ & $0.870^{*}$ & $0.967^{* *}$ \\
\hline Haliangium & $-0.971^{* *}$ & $-0.955^{* *}$ & $0.876^{*}$ & $0.929^{* *}$ & $0.955^{* *}$ \\
\hline Nitrospira & $-0.940^{* *}$ & $-0.957^{* *}$ & $0.970^{* *}$ & $0.910^{*}$ & $0.926^{* *}$ \\
\hline Gemmatimonas & $0.927^{* *}$ & $0.978^{* *}$ & $-0.986^{* *}$ & $-0.876^{*}$ & $-0.939^{* *}$ \\
\hline Lysobacter & $-0.965^{* *}$ & $-0.982^{* *}$ & $0.988^{* *}$ & $0.922^{* *}$ & $0.936^{* *}$ \\
\hline Acidobacteria_bacterium & $-0.969^{* *}$ & $-0.984^{* *}$ & $0.966^{* *}$ & $0.952^{* *}$ & $0.943^{* *}$ \\
\hline Bryobacter & $-0.954^{* *}$ & $-0.994^{* *}$ & $0.972^{* *}$ & $0.915^{*}$ & $0.957^{* *}$ \\
\hline Gaiella & $0.977^{* *}$ & $0.958^{* *}$ & $-0.929^{* *}$ & $-0.916^{*}$ & $-0.872^{*}$ \\
\hline Ilumatobacter & 0.597 & 0.708 & -0.666 & -0.584 & $-0.823^{*}$ \\
\hline Solirubrobacter & $0.835^{*}$ & $0.881^{*}$ & $-0.828^{*}$ & -0.757 & -0.792 \\
\hline Nocardioides & 0.793 & $0.876^{*}$ & $-0.939^{* *}$ & -0.746 & -0.776 \\
\hline Pseudarthrobacter & $-0.873^{*}$ & -0.803 & $0.825^{*}$ & 0.744 & $0.843^{*}$ \\
\hline
\end{tabular}

SWC, soil water content; ECe, saturation conductivity; SOM, soil organic matter; TN, soil total nitrogen. Correlation significant at $* 0.05$ or $* * 0.01$.

accumulation of strong acidic ions (e.g., $\mathrm{NO}_{3}^{-}, \mathrm{SO}_{4}^{2-}$, and $\mathrm{Cl}^{-}$) in salinized soil [18]. The decline in SOM observed as irrigation water salinity increased can be explained primarily because of reduced organic matter input due to reduced plant growth in saline soils [19]. In this study, saline-water irrigation also significantly decreased the biomass and yield of cotton. Biomass and yield were significantly negatively correlated with SWC and ECe but were significantly positively correlated with SOM and TN.
According to previous studies, salt broadly suppresses soil microbial communities and their biochemical activities [19, 20]. In this study, salinewater irrigation led to significant increases in ACE, Chaol, and Simpson indexes but to a significant decrease in the Shannon diversity index. The increases in Chaol and ACE indexes indicated that salt stress increased the richness of bacterial communities [21]. Chen et al. [11] also reported increases in Chaol and ACE indexes with increases in irrigation water salinity. a)

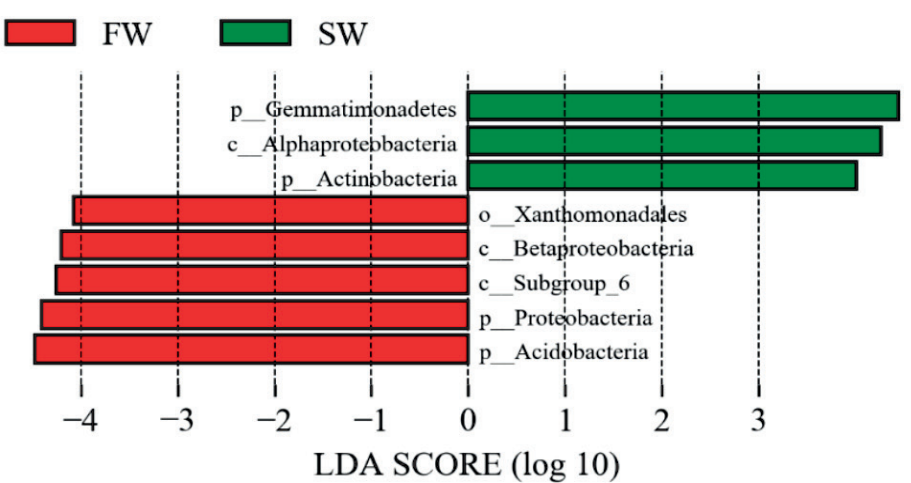

b)

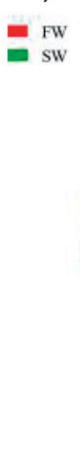

Cladogram

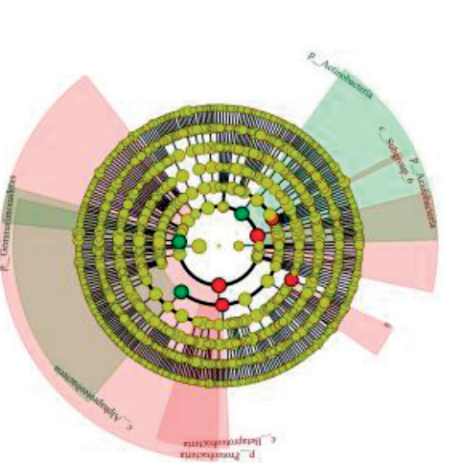

Fig. 9. Least discriminant analysis (LDA) effect size taxonomic cladogram comparing bacterial communities with a score higher than four. a) Histogram of the LDA scores for differentially abundant groups between irrigation treatments. The threshold on the logarithmic LDA score for discriminative features was set at 4.0. b) Cladogram for the taxonomic representation of significant differences among groups. Nodes from inside to outside the circle represent the bacterial taxa from phylum to species level. Differences between treatments are represented in the color of the most abundant taxa (red, FW; green, SW). The diameter of a node is positively correlated with the relative abundance of the taxon. 
The decrease in the Shannon index indicated that salt stress decreased the diversity of bacterial communities.

Many studies find that salinity affects the composition of soil microbial communities [22, 23]. In this study, the dominant phyla were Proteobacteria, Acidobacteria, Gemmatimonadetes, and Actinobacteria. These 4 phyla are also documented in soils under different situations in other studies [24, 25]. Both Proteobacteria and Actinobacteria contain representatives of the most abundant halophilic bacteria occurring in saline soils [24]. In the current study, irrigation with saline water markedly decreased the relative abundance of Proteobacteria and Acidobacteria but increased the relative abundance of Gemmatimonadetes and Actinobacteria.

The dominant genera in the Proteobacteria in this study are widely detected in saline soil [24]. The decrease in the relative abundance of Proteobacteria in the SW treatment was mainly due to reductions in the relative abundance of the genera H16, Haliangium, Nitrospira, and Lysobacter. Dong et al. [26] reported that members of the Acidobacteria represent significant proportions of bacterial communities in saline sediments. In this study, Acidobacteria was the second most abundant phylum. According to other studies, Acidobacteria is the dominant phylum in moderately saline soils but is absent in low and high saline soils [21, 27, 28]. In previous studies, the relative abundance of Acidobacteria was negatively correlated with soil pH [29] and positively correlated with soil organic carbon content [30], which are results consistent with those of the present study. Reductions in the relative abundance of the genera B41, Acidobacteria_bacterium, and Bryobacter primarily explained the decrease in the relative abundance of Acidobacteria in the SW treatment.

The phylum Gemmatimonadetes was the third most abundant in this study. The assignments attributed to this phylum showed a relatively high abundance with salinewater irrigation. The increase in the relative abundance of Gemmatimonadetes in the SW treatment was mainly due to the increase in the relative abundance of the genus Gemmatimonas. The phylum Actinobacteria was the fourth most abundant in this study. Sardinha et al. [31] and Valenzuela-Encinas et al. [32] also found that approximately $10 \%$ of sequences could be assigned to the phylum Actinobacteria. Valenzuela-Encinas et al. [27] reported that Actinobacteria are found in soils with low or intermediate salt concentrations but not in soils with high salt concentrations. The increase in the relative abundance of Actinobacteria in the SW treatment was mainly due to increases in the relative abundance of the genera Gaiella, Solirubrobacter, and Nocardioides.

Irrigation with saline water also reduced the relative abundance of the phylum Nitrospirae. The Nitrospirae consists of nitrite-oxidizing bacterial species with a marked chemolithoautrophic nature. The reduction in the relative abundance of the genus Nitrospira primarily explained the decrease in the relative abundance of Nitrospirae in the SW treatment. The Nitrospirae have been the subject of relatively few studies, even though these nitrite-oxidizing bacteria are key players in the soil $\mathrm{N}$ cycle. Zheng et al. [28] found that members of Nitrospirae are sensitive to salt and abundances decrease significantly in high-salt environments. Such decreases may be explained by other groups (such as Gemmatimonadetes or Chloroflexi) becoming more competitive. For example, the phylum Chloroflexi is generally found in hypersaline environments [27] and includes potential phototrophs. Previous studies also report that the abundance of Bacteroidetes increases as salinity increases [25, 33], although others report the opposite $[8,11]$.

Minor phyla and their associated genera were also identified in this study. For example, in the SW treatment, the relative abundance of the phylum Saccharibacteria increased but that of Verrucomicrobia significantly decreased. The decrease in the abundance of the phylum Verrucomicrobia could be explained by the significant correlation with SOM, which is consistent with the conclusion reported by Canfora et al. [8]. A previous study found that the phylum Firmicutes is suitable for bioremediation in hypersaline conditions [34]. In this study, the relative abundance of Firmicutes was not significantly different between the FW and SW treatments. Bacillus, an important resource for exploring halophilic enzymes and metabolic pathways in saline soil [35], was the dominant genus assigned to Firmicutes. However, the relative abundance of Bacillus decreased in the SW treatment.

The RDA indicated that soil salinity and $\mathrm{pH}$ were the major factors influencing the structure of soil bacterial communities. At the phylum level, Proteobacteria, Acidobacteria, Nitrospirae, Planctomycetes, Verrucomicrobia, Armatimonadetes, Latescibacteria, and Elusimicrobia had a negative relation with soil salinity, whereas Gemmatimonadetes, Actinobacteria, Chloroflexi, Bacteroidetes, and Saccharibacteria had a positive relation. However, previous studies found that Gemmatimonadetes, Acidobacteria, Nitrospirae, and Chloroflexi are also negatively correlated with soil salinity $[36,37]$. In this study, $\mathrm{pH}$ was negatively correlated with salinity, indicating that $\mathrm{pH}$ indirectly affected bacterial community composition via other soil properties. Zhou et al. [38] also reported negative correlations between the abundance of Actinobacteria and Bacteroidetes and soil $\mathrm{pH}$. In this study, the genera Gaiella, Ilumatobacter, Solirubrobacter, and Nocardioides in the phylum Actinobacteria also had a negative linear response with $\mathrm{pH}$ values. Moreover, in this study, the phyla Proteobacteria and Acidobacteria were significantly positively correlated with $\mathrm{pH}$. According to the LEfSe analysis, the increase in salinity of irrigation water reduced the number of potential bacterial biomarkers. Thus, soil bacterial communities adapted to salinity stress by adjusting their species composition. 


\section{Conclusions}

Long-term (10-year) saline-water irrigation significantly increased soil salinity but decreased soil $\mathrm{pH}, \mathrm{SOM}$, and TN. Soil bacterial community diversity (Shannon index) also decreased significantly with saline water irrigation. Compared with fresh water irrigation, saline water irrigation markedly increased the relative abundance of the phyla Gemmatimonadetes, Actinobacteria, Chloroflexi, and Saccharibacteria as well as the genera Gemmatimonas, Gaiella, Solirubrobacter, and Nocardioides. By contrast, saline water decreased the relative abundance of the phyla Proteobacteria, Acidobacteria, Nitrospirae, Planctomycetes, and Verrucomicrobia and the genera RB41, H16, Haliangium, Nitrospira, Lysobacter, Acidobacteria_bacterium, and Bryobacter. The RDA revealed that soil salinity and $\mathrm{pH}$ were the major drivers affecting the structure of bacterial communities. Thus, the changes in soil chemical properties with long-term saline-water irrigation reduced soil bacterial community diversity and decreased cotton growth and thereby cotton biomass and yield. These results increase our understanding of soil biological processes under saline water irrigation in arid areas.

\section{Acknowledgements}

This work was jointly funded by The National Natural Science Foundation of China [41661055], the Youth Innovation Talent Cultivation Program of Shihezi University [CXRC201706], the Open Fund of Key Laboratory of Northwest Oasis Agro-Environment, Ministry of Agriculture of China (NYBXBLZ-201701), and Xinjiang Cotton Quality Improvement and Efficiency Innovation Project.

\section{Conflict of Interest}

The authors declare no conflict of interest.

\section{References}

1. WANG R., KANG Y., WAN S., HU W., LIU S., LIU S. Salt distribution and the growth of cotton under different drip irrigation regimes in a saline area. Agricultural Water Management, 100 (1), 58, 2011.

2. ZHOU J.L., WU B., WANG Y.P., GUO X.J. Distribution and quality assessment of medium salinity groundwater in plain areas in Tarim Basin, Xinjiang. China Rural Water Hydropower, 9, 32, 2009.

3. BELTRAN J.M. Irrigation with saline water: benefits and environmental impact. Agricultural water management, 40 (2-3), 183, 1999.

4. WONG V.N., GREENE R.S.B., DALAL R.C., MURPHY B.W. Soil carbon dynamics in saline and sodic soils: a review. Soil Use and Management, 26 (1), 2, 2010.
5. PEREIRA L.S., CORDEY I., IACOVIDES I. Coping With Water Scarcity. Unesco, Paris, 2002.

6. HE J.Z., GE Y., XU Z., CHEN C. Linking soil bacterial diversity to ecosystem multifunctionality using backwardelimination boosted trees analysis. Journal of Soils and Sediments, 9 (6), 547, 2009.

7. SHEN J.P., XU Z., HE J.Z. Frontiers in the microbial processes of ammonia oxidation in soils and sediments. Journal of soils and sediments, 14 (6), 1023, 2014.

8. CANFORA L., BACCI, G., PINZARI F., PAPA G.L., DZAAI C., BENEDETTI A. Salinity and bacterial diversity: to what extent does the concentration of salt affect the bacterial community in a saline soil?. PLoS One, 9 (9), e106662, 2014.

9. ELMAJDOUB B., BARNETT S., MARSCHNER P. Response of microbial activity and biomass in rhizosphere and bulk soils to increasing salinity. Plant and soil, 381 (1-2), 297, 2014.

10. HU Y., WANG L., FU X., YAN J., WU J., TSANG Y., LE Y.Q., SUN Y. Salinity and nutrient contents of tidal water affects soil respiration and carbon sequestration of high and low tidal flats of Jiuduansha wetlands in different ways. Science of the Total Environment, 565, 637, 2016.

11. CHEN L., LI C., FENG Q., WEI Y., ZHENG H., ZHAO Y., FENG Y., LI H. Shifts in soil microbial metabolic activities and community structures along a salinity gradient of irrigation water in a typical arid region of China. Science of the Total Environment, 598, 64, 2017.

12. DEB S., MANDAL B., BHADORIA P.B.S., SCHULZ E., GHOSH S., DEBNATH M.K. Microbial biomass and activity in relation to accessibility of organic carbon in saline soils of coastal agro-Ecosystem. Proceedings of the National Academy of Sciences, India Section B: Biological Sciences, 88 (2), 633, 2018.

13. BOYRAHMADI M., RAIESI F. Plant roots and species moderate the salinity effect on microbial respiration, biomass, and enzyme activities in a sandy clay soil. Biology and Fertility of Soils, 54 (4), 509, 2018.

14. KRASHEVSKA V., KLARNER B., WIDYASTUTI R., MARAUN M., SCHEU S. Impact of tropical lowland rainforest conversion into rubber and oil palm plantations on soil microbial communities. Biology and fertility of soils, 51 (6), 697, 2015.

15. LOZUPONE C.A., KNIGHT R. Global patterns in bacterial diversity. Proceedings of the National Academy of Sciences, 104 (27), 11436, 2007.

16. AHMED C.B., MAGDICH S., ROUINA B.B., BOUKHRIS M., ABDULLAH F.B. Saline water irrigation effects on soil salinity distribution and some physiological responses of field grown Chemlali olive. Journal of environmental management, 113, 538, 2012.

17. MALASH N.M., FLOWERS T.J., RAGAB R. Effect of irrigation methods, management and salinity of irrigation water on tomato yield, soil moisture and salinity distribution. Irrigation Science, 26 (4), 313, 2008.

18. FAN Q.F., ZHANG Y.L., CHEN Z., WANG L.N., LOU Y.L. Effects of soil salinity accumulating and ion constitution on $\mathrm{pH}$ in the soil of protected field. Agricultural Research in the Arid Areas, 1, 006, 2009.

19. RIETZ D.N., HAYNES R.J. Effects of irrigation-induced salinity and sodicity on soil microbial activity. Soil Biology and Biochemistry, 35 (6), 845, 2003.

20. YUAN B.C., LI Z.Z., LIU H., GAO M., ZHANG Y.Y. Microbial biomass and activity in salt affected soils under arid conditions. Applied Soil Ecology, 35 (2), 319, 2007. 
21. YANG H., HU J., LONG X., LIU Z., RENGEL Z. Salinity altered root distribution and increased diversity of bacterial communities in the rhizosphere soil of Jerusalem artichoke. Scientific reports, 6, 20687, 2016.

22. KHALILOVA E.A., KOTENKO S.T., IALAMMAGOMEDOVA E.A., GASANOV R.Z., ABAKAROVA A.A., ALIVERDIEVA D. AExtremophilic microbial communities of saline soils and their diversity in the regions of the Caspian Depression. Arid Ecosystems, 7 (2), 116, 2017.

23. IWAOKA C., IMADA S., TANIGUCHI T., DU S., YAMANAKA N., TATENO R. The impacts of soil fertility and salinity on soil nitrogen dynamics mediated by the soil microbial community beneath the halophytic shrub tamarisk. Microbial ecology, 75 (4), 985, 2018.

24. MA B., GONG J. A meta-analysis of the publicly available bacterial and archaeal sequence diversity in saline soils. World Journal of Microbiology and Biotechnology, 29 (12), 2325, 2013.

25. WANG Z., LUO G., LI J., CHEN S.Y., LI Y., LI W.T., LI A.M. Response of performance and ammonia oxidizing bacteria community to high salinity stress in membrane bioreactor with elevated ammonia loading. Bioresource technology, 216, 714, 2016.

26. DONG H., ZHANG G., JIANG H., YU B., CHAPMAN L.R., LUCAS C.R., FIELDS M.W. Microbial diversity in sediments of saline Qinghai Lake, China: linking geochemical controls to microbial ecology. Microbial Ecology, 51(1), 65, 2006.

27. VALENZUELA-ENCINAS C., NERIA-GONZALEZ, I., ALCANTARA-HERNANDEZ, R.J., ESTRADAALVARADO, I., DENDOOVEN L., MARSCH R. Changes in the bacterial populations of the highly alkaline saline soil of the former lake Texcoco (Mexico) following flooding. Extremophiles, 13 (4), 609, 2009.

28. ZHENG W., XUE D., LI X., DENG Y., RUI J., FENG K., WANG Z.L. The responses and adaptations of microbial communities to salinity in farmland soils: A molecular ecological network analysis. Applied Soil Ecology, 120, 239, 2017.

29. SAIT M., DAVIS K.E., JANSSEN P.H. Effect of $\mathrm{pH}$ on isolation and distribution of members of subdivision 1 of the phylum Acidobacteria occurring in soil. Applied and environmental microbiology, 72 (3), 1852, 2006.
30. RAWAT S.R., MANNISTO M.K., BROMBERG Y., HAGGBLOM M.M. Comparative genomic and physiological analysis provides insights into the role of Acidobacteria in organic carbon utilization in Arctic tundra soils. FEMS microbiology ecology, 82 (2), 341, 2012.

31. SARDINHA M., MULLER T., SCHMEISKY H., JOERGENSEN R.G. Microbial performance in soils along a salinity gradient under acidic conditions. Applied Soil Ecology, 23 (3), 237, 2003.

32. VALENZUELA-ENCINAS C., ALCANTARAHERNANDEZ R.J., ESTRADA-ALVARADO I., ZAVALA-DIAZ F.J., DENDOOVEN L., MARSCH $\mathrm{R}$. The archaeal diversity and population in a drained alkaline saline soil of the former Lake Texcoco (Mexico). Geomicrobiology Journal, 29 (1), 18, 2012.

33. KESHRI J., MODY K., JHA B. Bacterial community structure in a semi-arid haloalkaline soil using culture independent method. Geomicrobiology Journal, 30 (6), $517,2013$.

34. NICHOLSON C.A., FATHEPURE B.Z. Aerobic biodegradation of benzene and toluene under hypersaline conditions at the Great Salt Plains, Oklahoma. FEMS Microbiology Letters, 245 (2), 257, 2005.

35. LISZKA M.J., CLARK M.E., SCHNEIDER E., CLARK D.S. Nature versus nurture: developing enzymes that function under extreme conditions. Annual review of chemical and biomolecular engineering, 3, 77, 2012.

36. KIM J.M., ROH A.S., CHOI S.C., KIM E.J., CHOI M.T., AHN B.K., KIM S.K., LEE Y.H., JOA J.H., KANGS.S., LEE S.A. Soil $\mathrm{pH}$ and electrical conductivity are key edaphic factors shaping bacterial communities of greenhouse soils in Korea. Journal of Microbiology, 54 (12), 838, 2016

37. CHENG Z., ZHANG F., GALE W.J., WANG W., SANG W., YANG $\mathrm{H}$. Effects of reclamation years on composition and diversity of soil bacterial communities in Northwest China. Canadian journal of microbiology, 64 (1), 28, 2017.

38. ZHOU J., GUAN D.W., ZHOU B.K., ZHAO B.S., MA M.C., QIN J., JIANG X., CHEN S.F., CAO F.M., SHEN D.L., LI J. Influence of 34-years of fertilization on bacterial communities in an intensively cultivated black soil in northeast China. Soil Biology and Biochemistry, 90, 42, 2015. 